\title{
COVID-19 Lockdowns Improve Air Quality in the South-East Asian Regions, as Seen by the Remote Sensing Satellites
}

\author{
Abirlal Metya ${ }^{1,2 *}$, Panini Dagupta ${ }^{1,3}$, Santanu Halder ${ }^{1,2}$, S. Chakraborty ${ }^{1,2}$, Yogesh K. Tiwari ${ }^{1,2}$ \\ ${ }^{1}$ Center for Climate Change Research, Indian Institute of Tropical Meteorology, MoES, Pune, India \\ ${ }^{2}$ Department of Atmospheric and Space Sciences, Savitribai Phule Pune University, Pune, India \\ ${ }^{3}$ Department of Meteorology and Oceanography, College of Science and Technology, Andhra University, Visakhapatnam, \\ Andhra Pradesh, India
}

\begin{abstract}
The appearance of COVID-19 in December, 2019 in China and its rapid spread all over the globe, forced the governments to severely curb the social and economic activities of their respective countries. Barring the essential services, most of the business activities and transport sectors have been suspended and an unprecedented lockdown imposed over major economies in the world. South-East Asian regions, such as India and China, were no different. As a result, the pollutant level has gone down over these regions, and the air quality improved somewhat better than it was before the lockdown. This study uses satellite retrievals and attempts to estimate the extent of the reduction of major pollutants, like carbon monoxide (CO), nitrogen dioxide $\left(\mathrm{NO}_{2}\right)$ and sulfur dioxide $\left(\mathrm{SO}_{2}\right)$ in India and China during January to April, 2020. We have calculated anomalies of pollutants during the lockdown period relative to their long-term records. $\mathrm{NO}_{2}$, which has significant emissions from the transport sector, is reduced on an average by $17 \%$ over India and $25 \%$ over China. $\mathrm{SO}_{2}$, which mainly emits from power plants, shows significant reductions (approx. 17\%) especially over the Eastern sector of India. CO is found to be reduced by $6.5 \%$ over north-central China. The differential reduction was attributed to man made versus natural activities. This study is helpful to policy makers in mitigating the air-pollution on a long-term perspective.
\end{abstract}

Keywords: SARS-CoV-2; Coronavirus; COVID-19; Air quality; $\mathrm{CO} ; \mathrm{NO}_{2} ; \mathrm{SO}_{2}$.

\section{INTRODUCTION}

Coronavirus disease 2019 (COVID-19) is a novel pneumonia caused by severe acute respiratory syndrome coronavirus 2 (SARS-CoV-2). COVID-19 is the seventh coronavirus known to affect humans (Andersen et al., 2020). This novel coronavirus was first reported in December, 2019 in Wuhan, the capital of China's Hubei province. Since then, it has transmitted across the nations within a very short time. Due to the rapid spread across the globe, the World Health Organization (WHO) declared COVID-19 as a pandemic on March 11, 2020. Till April 29, 2020, 3,018,952 cases have been confirmed globally, with 207,973 deaths, according to WHO (2020). International travel is believed to have potential effects (Bogoch et al., 2020) in the rapid spreading of the virus across the globe.

Lockdown measures have been implemented by the governments and regulatory agencies across the world to

\footnotetext{
* Corresponding author.

Tel.: 9732789387

E-mail address: abirmetya92@gmail.com
}

maintain person to person 'social distancing' to minimize the virus infection. As a result, economic activities, such as social events, agricultural practices, travel, and tourism, etc. have come to a near halt. Business activities are drastically reduced, and people are forced to 'work from home'. Such a situation has resulted in an unprecedented effect on the environment. Due to the strict enforcement of vehicular movement, the emission level has dramatically reduced. As a result, air quality has significantly improved. Few previous instances show short time emission control measures (ECM) improved regional air quality. For example, ECM imposed during 2008-Olympic and Paralympic games held in Beijing, China, improved air quality over Beijing and surrounding regions for almost two months (July-September). A reduction of $43 \%, 13 \%$ and $12 \%$ in total column $\mathrm{NO}_{2}\left({ }^{\mathrm{TC}} \mathrm{NO}_{2}\right)$, boundary layer $\mathrm{SO}_{2}\left({ }^{\mathrm{BL}} \mathrm{SO}_{2}\right)$ and $700 \mathrm{hPa} \mathrm{CO}\left(\mathrm{CO}_{700}\right)$ with respect to the last three years was observed over Beijing and surrounding regions due to strict traffic movements and controls on pollutant emission (Witte et al., 2009). Air quality improvement during 2008-Beijing Olympics was also reported by Wang et al. (2010) and Shen et al. (2011). Temporary restriction in traffic movements was found to improve air quality in the 2004 Athens Olympics (Frantzeskakis and Frantzeskakis 2006; Shen et al., 2011), the 2002 Busan Asian 
Games (Lee et al., 2007) and the 1996 Atlanta Olympics (Friedman et al., 2001). Recently, a significant drop in pollutant levels has been reported; for example, Spain, one of the badly infected countries, reported a $90 \%$ drop in vehicular traffic and a corresponding level of pollution (Barbuzano 2020).

Very strict lockdown measure was implemented by the Indian and the Chinese governments due to their vast population (1.35 and 1.39 billion respectively). Hence its effect on air quality is expected to be significant and such kind of studies have been recommended (Saraswat and Saraswat 2020). To study the "lockdown effect" on the pollutants, we have analyzed the remote sensing data of a few atmospheric pollutants; these are Carbon Monoxide (CO), Sulfur dioxide $\left(\mathrm{SO}_{2}\right)$ and the oxides of nitrogen $\left(\mathrm{NO}_{\mathrm{x}}\right)$, mainly the $\mathrm{NO}_{2}$. Air pollution has an impact on air quality (Monks et al., 2009), climate, health (WHO 2016), and visibility (Wang et al., 2012). Carbon monoxide (CO), Nitrogen dioxide $\left(\mathrm{NO}_{2}\right)$ and Sulfur dioxide $\left(\mathrm{SO}_{2}\right)$ are very toxic, gaseous air pollutants and produced by anthropogenic activities like-vehicular emission, power plants, manufacturing, real estate activities etc. as well as natural sources like- biomass burning, soil emission, and lightning. These pollutants can be emitted locally or can be reached by large-scale transport due to meteorology, depending upon pollutant lifetime, chemical reactivity, and wind circulation (Maas et al., 2016; Sawlani et al., 2019). In this study, we used satellite retrieved Carbon Monoxide (CO), Sulfur dioxide $\left(\mathrm{SO}_{2}\right)$, and Nitrogen Dioxide $\left(\mathrm{NO}_{2}\right)$ concentration to explore COVID-19 induced lockdown effect on these gases over the South-East Asian region mainly over India and China.

\section{DATA AND METHODOLOGY}

\section{Study Area}

Fig. 1(a) shows the two study areas, India, and eastern China, where the virus was believed to have originated. The population density is shown by blue shading. Population data was taken from Socioeconomic Data and Applications Center (SEDAC, https://sedac.ciesin.columbia.edu/data/col lection/gpw-v4). The geographical extent of the study areas denoted as (a) India box (IN-box): $70-92^{\circ} \mathrm{E}$ and $8-33^{\circ} \mathrm{N}$ and (b) China box (CH-box): $103-122^{\circ} \mathrm{E}$ and $22-40^{\circ} \mathrm{N}$. IN-box includes a major portion of India (except north-east India), Bangladesh, Nepal, Bhutan, part of Sri Lanka, part of Pakistan and part of Tibetan plateau. Eastern China is the main part of the CH-box. It is evident that the total population in INbox increased sharply in the last twenty years than the $\mathrm{CH}$ box. Moreover, these two boxes, which cover almost an area of $\sim 1.37 \%$ of the earth, contain $\sim 33 \%$ of the total population of the globe. These two regions saw rapid industrialization and socio-economic growth in the last few decades. Moreover, EDGAR v4.3.2 emission inventory data show a shift of top $\mathrm{CO}, \mathrm{SO}_{2}$, and $\mathrm{NOx}$ emission regions from USA and Europe in 1970 to India and China in 2012 (Crippa et al., 2018). As a result, these two regions suffer from poor air quality.

As mentioned earlier, the government of both countries took very strict measures to contain the spread of the deadly virus. Mass movements were restricted by curbing public transports (bus, train, airplane, etc.), large gatherings were banned, school colleges were closed, and the people were obliged to stay at home. Such measures prove sufficient promises to slow down the spreading of the virus as well as improve air quality in several parts of the world.

\section{Air Quality Data}

The Atmospheric Infrared Sounder (AIRS), polar-orbiting Aqua satellite launched by NASA on May 4, 2002, was aimed to monitor global water and energy cycles. As a part, it measures atmospheric CO. This sun-synchronous satellite has a 16-day repeat cycle. AIRS provides daily level-3 global $\mathrm{CO}$ averaged over $1^{\circ} \times 1^{\circ}$ grid cells associated with 24 standard pressure levels. We used a version- 6 ascending product of the satellite. The data quality and stability can be found in (Susskind et al., 2014). AIRS CO products are most sensitive to the mid-troposphere. Hence, we have taken CO from $700 \mathrm{hPa}$ level in the study and denoted as $\mathrm{CO}_{700}$.

Ozone Monitoring Instrument (OMI) was launched in July, 2004 onboard NASA's Aura satellite. It is a DutchFinnish nadir-viewing hyperspectral imaging spectrometer
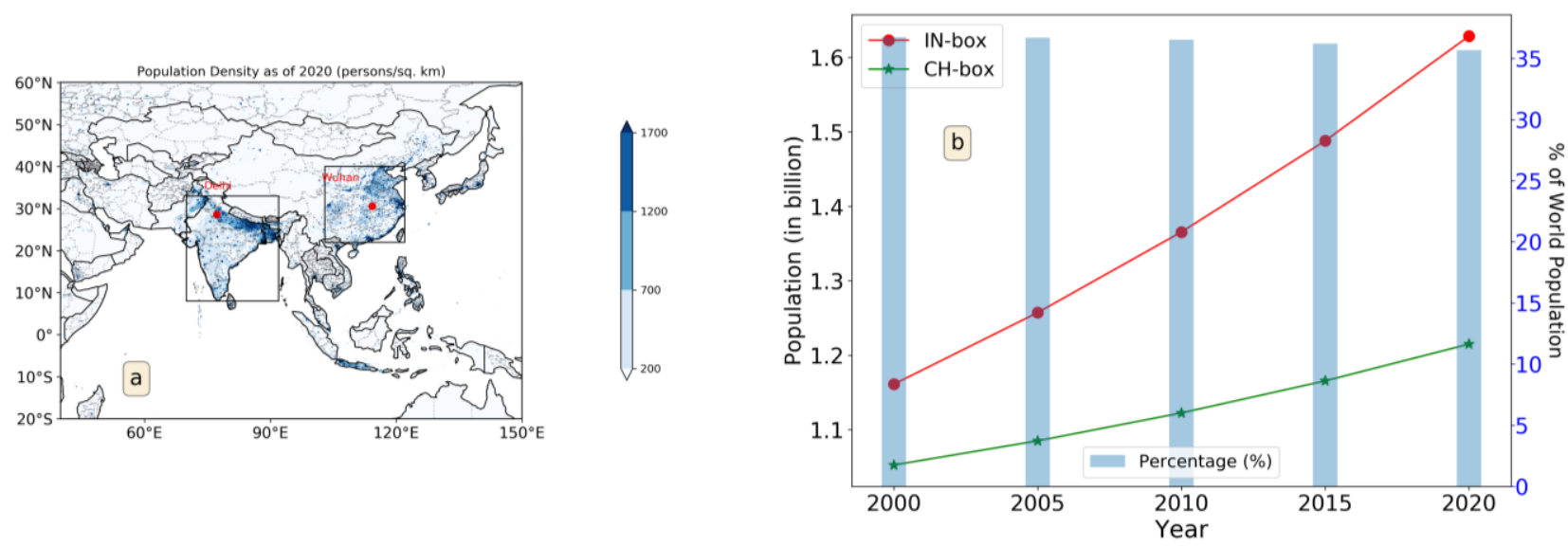

Fig. 1. Shows population density (persons/sq. $\mathrm{km}$ ). Two densely populated areas (IN-box and CH-box) are marked by squared boxes. (b) shows a change in the total population of IN-box and CH-box in the last 20-years by the red and green line respectively. Bars are the percentage of the world population that lives within the two regions. 
flying on a sun-synchronous orbit crossing the local equator between 13:40 and 13:50 LT. OMI measures in the UVvisible wavelength range $(270-500 \mathrm{~nm})$ at a nadir resolution of $13 \times 24 \mathrm{~km}$. OMI obtained atmospheric $\mathrm{SO}_{2}$ measurement in the UV-wavelength $(310.5-340 \mathrm{~nm})$ and $\mathrm{NO}_{2}$ measurements in the $405-460 \mathrm{~nm}$ (Visible-range).

OMI tropospheric column $\mathrm{NO}_{2}$ daily data, OMNO2d (Krotkov et al., 2017), is obtained from NASA-GES-DAAC (https://disc.gsfc.nasa.gov/datasets/OMNO2d_003/summary). It is a level-3 gridded product with $0.25^{\circ} \times 0.25^{\circ}$ grid resolution. OMI boundary layer $\mathrm{SO}_{2}$ daily data, OMSO2e (Krotkov et al., 2015), is obtained from NASA-GES-DAAC (https://disc.gsfc.nasa.gov/datasets/OMSO2e_003/summary). The level- 3 gridded product of $0.25^{\circ} \times 0.25^{\circ}$ grid resolution is obtained from an improved Band Residual Difference Algorithm (BRD). Tropospheric $\mathrm{NO}_{2}$ and boundary layer $\mathrm{SO}_{2}$ is denoted by ${ }^{\mathrm{TC}} \mathrm{NO}_{2}$ and ${ }^{\mathrm{BL}} \mathrm{SO}_{2}$ hereafter.

Moderate Resolution Imaging Spectroradiometer (MODIS) onboard NASA's Terra and Aqua satellites provides data from February, 2000 (Terra) and June, 2002 (Aqua). MODIS fire-products provide the location, timing, instantaneous radiative power, and smoldering ratio of actively burning fires (Kaufman et al., 1998). Near real-time (NRT) MODIS Thermal Anomalies / Fire locations - Collection 6 processed by NASA's Land, Atmosphere Near real-time Capability for EOS (LANCE) Fire Information for Resource Management System (FIRMS), using swath products (MOD14/MYD14). The NRT fire data is replaced with data extracted from the standard MCD14ML Active Fire/Thermal Anomalies locations (vector data), as it becomes available, usually after 2 months. Hence, fire-counts used in the text from 20132019 is standard product (MCD14ML) and data of 2020 is NRT product (MCD14DL).

The Emissions Database for Global Atmospheric Research (EDGAR) is a bottom-up emission database that provides country level as well as gridded emissions from several sectors for air pollutants as well as greenhouse gases from 1970 (Crippa et al., 2018).

\section{Detrend the Datasets}

The pollutants $\mathrm{CO}, \mathrm{NO}_{2}$, and $\mathrm{SO}_{2}$ show strong seasonality as well as annual trends. Some places show negative trends due to strong mitigation policies. While a lack of mitigation compliance leads to positive trends in other places. Hence, the data has been detrended on every $5^{\circ} \times 5^{\circ}$ grid box using a nonlinear regression model suggested by (van der A et al., 2017). In the present study, we have resampled the daily satellite data to a 10-day average for $\mathrm{NO}_{2}$ and monthlyaverage for $\mathrm{CO}$ and $\mathrm{SO}_{2}$. Hence, the nonlinear regression fitted to 10-day averaged data is:

$y_{t}=A+\frac{1}{36} B X_{t}+C \sin \left(\omega X_{t}+\phi\right)+R_{t}$

And, the equation for the monthly dataset is,

$y_{t}=A+\frac{1}{12} B X_{t}+C \sin \left(\omega X_{t}+\phi\right)+R_{t}$ where, $y_{t}$ represents the 10-day or monthly averaged time series of the pollutant, $X_{t}$ is 10-day or months from January $1,2010, R_{t}$ is the remainder and $\mathrm{A}, \mathrm{B}, \mathrm{C}, \phi$ are the fit parameters. A is constant of the fit, $\mathrm{B}$ is an annual trend, $\mathrm{C}$ is seasonal amplitude, $\omega(2 \Pi / 36)$ is frequency, and $\phi$ is a phase shift. B is the slope or linear trend of the time series. Then the time series were detrended by subtracting observed time series by $\frac{1}{36} B X_{t}$ or $\frac{1}{12} B X_{t}$ for a 10-day averaged or monthly dataset respectively.

\section{RESULTS AND DISCUSSION}

\section{Carbon Monoxide $\left(\mathrm{CO}_{700}\right)$}

Carbon monoxide (CO), an important air pollutant, is not only chemically colourless, odourless, and tasteless but also a toxic gas which is considered as an indirect greenhouse gas. Higher levels of $\mathrm{CO}$ can lead to serious health problems (Raub and Benignus, 2002). CO enters into the atmosphere from incomplete combustion of carbon mainly due to household combustion, industrial activities, road transport, and agricultural waste burning. The lifetime of $\mathrm{CO}$ is $1-$ 3 months (Cooper et al., 2002). The indirect radiative forcing of $\mathrm{CO}$ due to production of ozone $\left(\mathrm{O}_{3}\right)$ and carbon-di-oxide $\left(\mathrm{CO}_{2}\right)$ as well as modulating the lifetime and abundance of atmospheric methane $\left(\mathrm{CH}_{4}\right)$ is estimated to be $0.23(0.18-$ 0.29) $\mathrm{Wm}^{-2}$ (Myhre et al., 2014). CO emission from China is found to be stable (2005-2009) despite the rapid increase in energy consumption and industrial economy due to improvements in energy efficiency and emission control regulations (Zhao et al., 2012). We found a decrease in $\mathrm{CO}_{700}$ over China, the rate is $-1.58 \mathrm{ppb} \mathrm{yr}^{-1}$ and the rate over India is $-0.433 \mathrm{ppb} \mathrm{yr}^{-1}$ during 2010-2020. Hence, the monthlymean dataset was detrended using Eq. (2).

Figs. 2(a), 2(c), and 2(e) show the monthly anomaly of $\mathrm{CO}_{700}$. The climatology (2010-2020) of $\mathrm{CO}_{700}$ of JanuaryFebruary-March is shown in the supplementary section (Fig. S1(a)). China emits more $\mathrm{CO}$ than India. $\mathrm{CO}_{700}$ shows a clear seasonality over both regions. Both the areas show similar seasonality with maximum $\mathrm{CO}_{700}$ in spring (MarchApril-May) and minimum in summer (June-July-AugustSeptember). Monthly anomaly (in \%) of January, February, and March, 2020 of $\mathrm{CO}_{700}$ (Fig. 2, left column) as well as MODIS fire-count (Fig. 2, right column) is shown. Fig. 2(a) shows a positive anomaly in the central part of $\mathrm{CH}$-box in January, 2020. While Figs. 2(c) and 2(e) show a strong negative anomaly of -12 to $-20 \%$ in different regions of north-central China. A strong positive anomaly is observed at the same time in south-China becoming more positive in March. MODIS fire-count data shows a positive anomaly over the Indo-China peninsula, which turns out to be more positive in February and March. Monthly wind vectors at $700 \mathrm{hPa}$ level obtained from NCEP-NCAR reanalysis are also shown in Fig. 2 (left column).

Fig. 3(a) shows the change of $\mathrm{CO}_{700}$ over a smaller region of north-central China $\left(106-122^{\circ} \mathrm{E}\right.$ and $30-40^{\circ} \mathrm{N}$, shown in Fig. 2(c), denoted by squared box). The length of the bars presents a change in percentage from the long-term mean (2010-2020) in January (red), February (blue), and March 

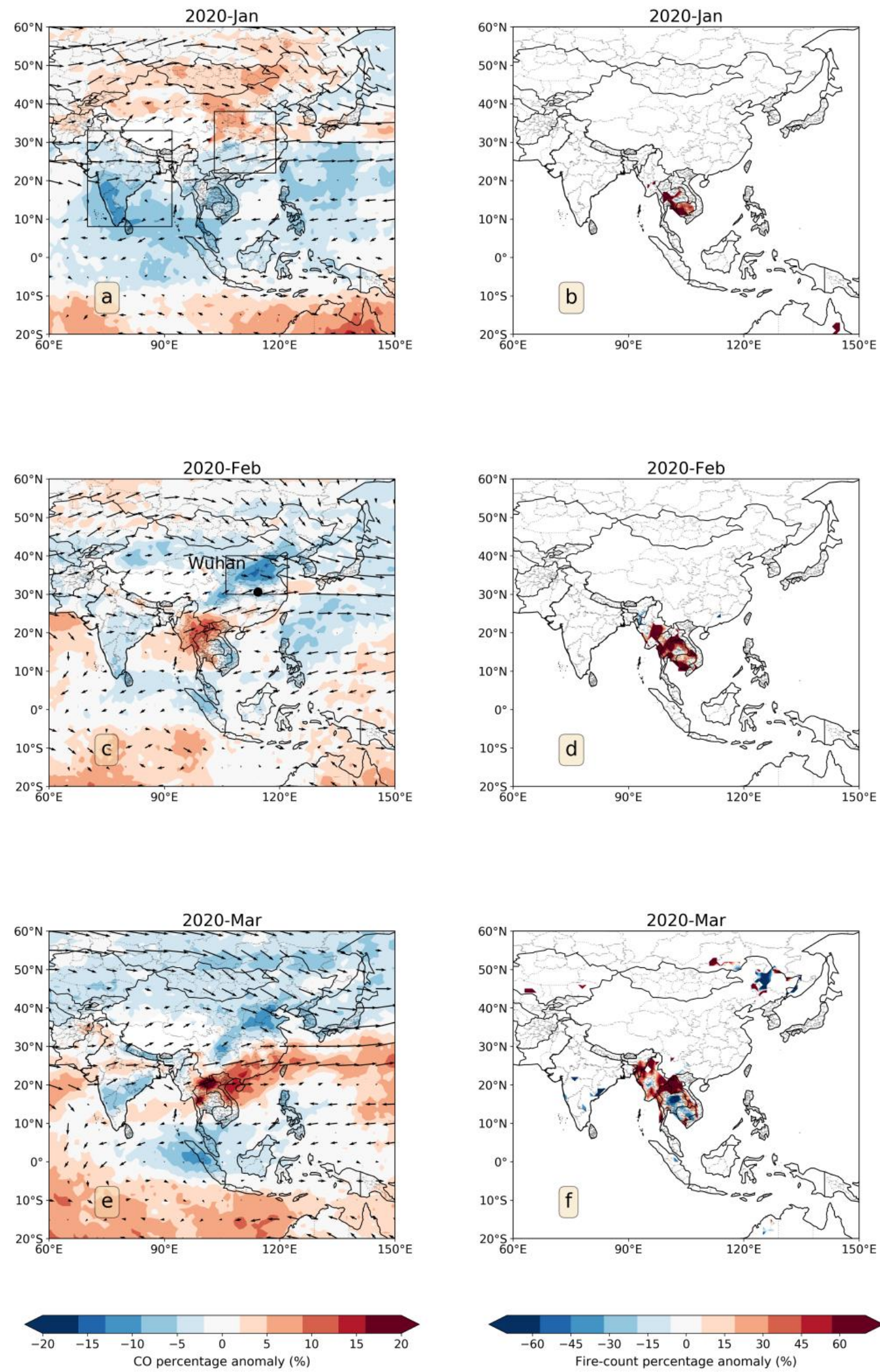

Fig. 2. Monthly anomaly of $\mathrm{CO}_{700}$ for (a) January-2020 and (c) February, 2020 (e) March, 2020. Corresponding winds at $700 \mathrm{hPa}$ are shown as vectors taken from NCEP-NCAR. Monthly anomaly of MODIS fire-count in (b) January, 2020 (d) February, 2020 and (e) Mach, 2020. 

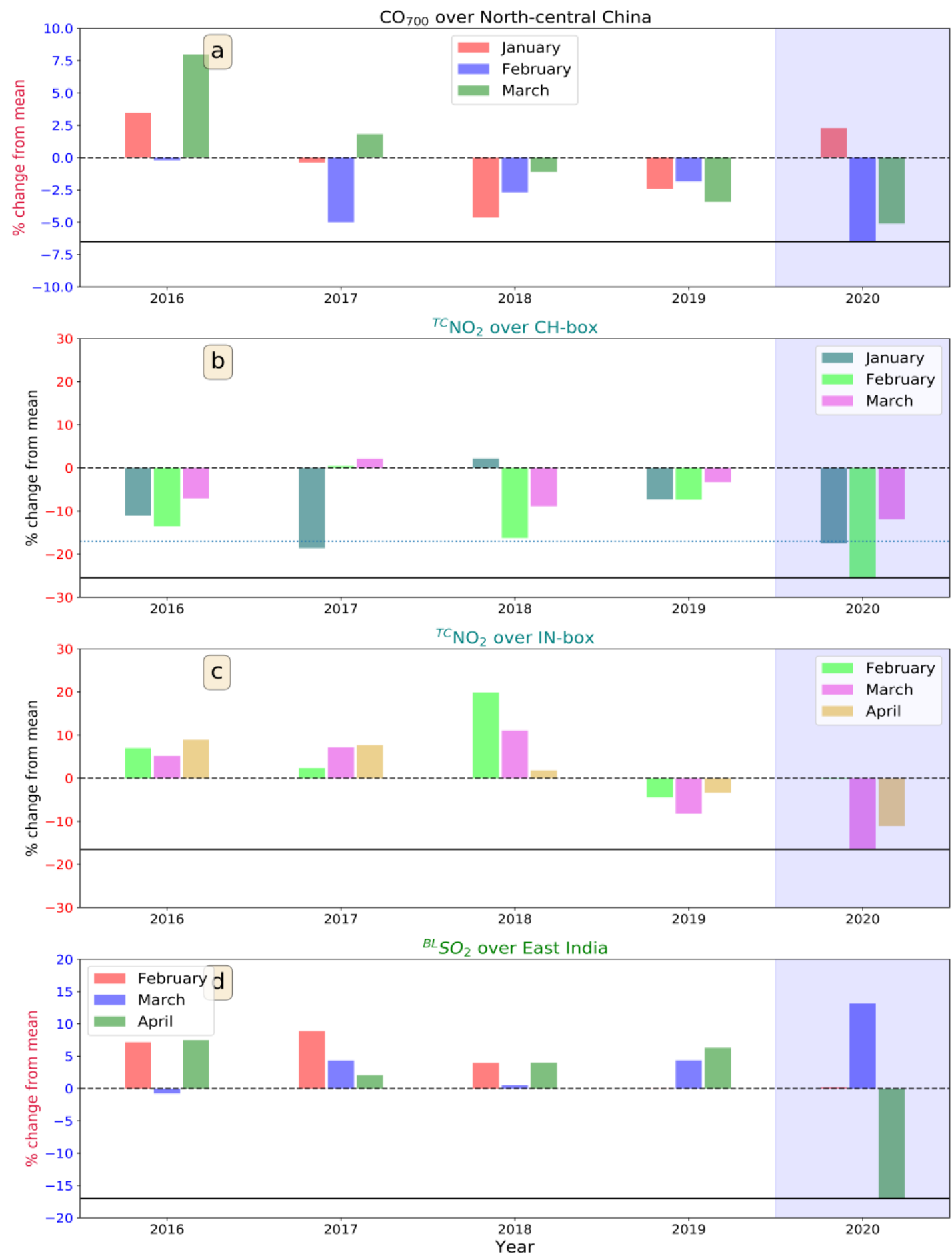

Fig. 3. Percentage change in $\mathrm{CO}_{700}$ relative to the mean (2010-2020) of individual years over (a) north-central China. Red: January, Blue: February, Green: March. (b) and (c) shows the percentage change in ${ }^{\mathrm{TC}} \mathrm{NO}_{2}$ relative to the mean (2010-2020) of individual years over $\mathrm{CH}$-box and IN-box, respectively. (d) shows the percentage change in ${ }^{\mathrm{BL}^{2}} \mathrm{SO}_{2}$ relative to the mean (2010-2020) of individual years over east-India.

(green). North-central China shows a significant reduction in $\mathrm{CO}_{700}$ in February and March. The maximum reduction is observed in February, about $\sim 6.5 \%$ from long term mean (2010-2020). March is also associated with a moderate decrease of about $\sim 5.1 \%$. The absolute values for northcentral China are also shown in Table 1. A significant reduction can be observed in the table during February (158.8 ppb) and March (164.7), 2020.

Global CO sources are mainly from anthropogenic activities (500-600 $\mathrm{Tg} \mathrm{yr}^{-1}$ ) and biomass burning (300-600 $\mathrm{Tg} \mathrm{yr}^{-1}$ ) (Zhang et al., 2020). Biomass burning plays an important role in global $\mathrm{CO}$ concentrations. On a regional scale, the 
Table 1. Time series of $\mathrm{CO}_{700},{ }^{\mathrm{TC}} \mathrm{NO}_{2}$ and ${ }^{\mathrm{BL}} \mathrm{SO}_{2}$ in January-April for the last 5-years. Significance (p-value) of the anomaly is derived using $\mathrm{z}$-statistics $(\mathrm{z}=x-\mu / \sigma)$.

\begin{tabular}{|c|c|c|c|c|c|c|}
\hline & \multirow{2}{*}{2016} & \multirow{2}{*}{2017} & \multirow{2}{*}{2018} & \multirow{2}{*}{2019} & \multicolumn{2}{|r|}{2020} \\
\hline & & & & & Mean & Anomaly \\
\hline \multicolumn{7}{|c|}{$\mathrm{CO}_{700}(\mathrm{ppb})$ for north-central China } \\
\hline January & 166.63 & 160.45 & 153.61 & 157.19 & 164.74 & $3.67(\mathrm{p}=0.27)$ \\
\hline February & 169.55 & 161.41 & 165.34 & 166.77 & 158.87 & $-11.035(\mathrm{p}=0.06)$ \\
\hline March & 187.38 & 176.69 & 171.62 & 167.6 & 164.68 & $-8.86(\mathrm{p}=0.07)$ \\
\hline \multicolumn{7}{|c|}{${ }^{\mathrm{TC}} \mathrm{NO}_{2}\left(\mu \mathrm{mol} \mathrm{m}{ }^{-2}\right)$ for $\mathrm{CH}-$ box } \\
\hline January & 169.05 & 154.75 & 194.31 & 176.22 & 156.87 & $-33.27(\mathrm{p}=0.08)$ \\
\hline February & 118.0 & 137.05 & 114.26 & 126.4 & 101.37 & $-35.07(\mathrm{p}=0.09)$ \\
\hline March & 120.1 & 132.07 & 117.77 & 125.02 & 113.85 & $-15.42(\mathrm{p}=0.12)$ \\
\hline \multicolumn{7}{|c|}{${ }^{\mathrm{TC}} \mathrm{NO}_{2}\left(\mu \mathrm{mol} \mathrm{m}{ }^{-2}\right)$ for IN-box } \\
\hline February & 25.1 & 24.02 & 28.13 & 22.42 & 23.41 & $-0.05(\mathrm{p}=0.5)$ \\
\hline March & 26.35 & 26.84 & 27.83 & 22.98 & 20.97 & $-4.1(\mathrm{p}=0.05)$ \\
\hline April & 26.31 & 26.0 & 24.58 & 23.33 & 21.47 & $-2.68(\mathrm{p}=0.03)$ \\
\hline \multicolumn{7}{|c|}{${ }^{{ }^{B L}} \mathrm{SO}_{2}\left(\mu \mathrm{mol} \mathrm{m}{ }^{-2}\right)$ for east-India } \\
\hline February & 169.5 & 172.28 & 164.49 & 158.16 & 158.52 & $0.32(\mathrm{p}=0.48)$ \\
\hline March & 137.54 & 144.64 & 139.35 & 144.64 & 156.82 & $18.2(\mathrm{p}=0.01)$ \\
\hline April & 125.56 & 119.21 & 121.48 & 124.16 & 96.82 & $-20.0(\mathrm{p}=0.01)$ \\
\hline
\end{tabular}

influence of biomass burning is also important in East Asia (Kang et al., 2019) and Southeast Asia (Yin et al., 2019). Hence, fire in the Indo-China peninsula with strong $700 \mathrm{hPa}$ wind produce positive $\mathrm{CO}$ anomaly over south-east China. On the other hand, the industry and transportation sector is the dominant $\mathrm{CO}$ emitter in the eastern and north-central China (Zhao et al., 2012). Hence, a decrease in CO over north-central China in February and March is most likely driven by a massive lockdown regulation. The lockdown effect is nearly absent in south-eastern China due to biomass burning in the Indo-China peninsula.

\section{Tropospheric $\mathrm{NO}_{2}\left({ }^{\mathrm{TC}} \mathrm{NO}_{2}\right)$}

$\mathrm{NO}_{2}$ is considered as one of the crucial atmospheric pollutants due to its severe effects on human health and plant growth (Sabljic, 2009). High $\mathrm{NO}_{2}$ levels can cause photochemical smog, acid rain, and nitrate aerosols. Indirectly it can affect the greenhouse gas budget by producing tropospheric ozone. High temperature combustion processes such as power plants and transport sectors emit $\mathrm{NO}_{\mathrm{x}}$. The top emitting $\mathrm{NO}_{2}$ centres have been shifted from the USA, Europe to India, and China from 1970-2012. Though $\mathrm{NO}_{2}$ lifetime is highly dependent on meteorology, length of night, temperature, $\mathrm{OH}$ and $\mathrm{H}_{2} \mathrm{O}$ concentration, daytime $\mathrm{NO}_{2}$ lifetime is $\sim 4$ to $\sim 8$ hours (Beirle et al., 2011). Even though the satellite provides a total column density of $\mathrm{NO}_{2}$ (upto $\sim 10$ $13 \mathrm{~km}$ ), the majority of $\mathrm{NO}_{2}$ molecules lie within the boundary layer, within lowermost 1-2 km (Boersma et al., 2009). Short lifetime and sensitivity to the boundary layer contribute to ${ }^{\mathrm{TC}} \mathrm{NO}_{2}$ as most sensitive to surface emission. Previous studies found an increasing trend in $\mathrm{NO}_{2}$ over India (Ramachandran et al., 2013; Ghude et al., 2008). In the last decade (2010-2020) an increasing trend of $+0.33 \mu \mathrm{mol} \mathrm{m}{ }^{-2} \mathrm{yr}^{-1}$ in ${ }^{\mathrm{TC}} \mathrm{NO}_{2}$ over the IN-box was observed. Stringent regulatory enforcement by China (Liu et al., 2016) led to a significant reduction of $\mathrm{NO}_{2}$ from 2011 onwards. We found $-4.26 \mu \mathrm{mol} \mathrm{m}^{-2} \mathrm{yr}^{-1}$ reduction of ${ }^{\mathrm{TC}} \mathrm{NO}_{2}$ during 2010-2020 over the CH-box.
The 10-day anomaly of ${ }^{\mathrm{TC}} \mathrm{NO}_{2}$ in percentage is shown in Figs. 4(a)-4(d). The date shown in the figure title is the day one of the 10-day anomalies i.e., Fig. 4(a) shows the mean anomaly of January 1 to January 10, 2020. A significant negative anomaly is evident during February over a large portion of China. However, the anomaly reduces from March fourth week and becomes positive in April. While a negative anomaly appears over India in March fourth week, it further intensified in April. The latitude-time plot, widely known as the Hovmöller diagram, is shown in Figs. 4(e) and 4(f). The negative anomaly was found all over the $\mathrm{CH}-$ box and concentrated between January second week to March first week (Fig. 4(e)). Large-scale negative anomaly persists over the IN-box from the third week of March (Fig. 4(f)). A nationwide lockdown was initiated by the Indian government from March 25, 2020, which forced about a billion people to stay at home, and restricted vehicular movements. The effect of lockdown is also seen in Fig. 4(c) and 4(d), which shows a large negative anomaly almost all over the IN-box. Google mobility data (Fig. S(3)) also shows a large decrease in mobility over India and neighbouring regions (Pakistan, Nepal, Sri-Lanka, and Indo-China region) from the third week of March. The retail and recreation sector, as well as transit stations, showed a substantial decrease $(\sim 80 \%)$ from baseline over India during lockdown (from $3^{\text {rd }}$ week of March, 2020).

Fig. 3(b) shows a $\sim 25 \%$ reduction of ${ }^{\mathrm{TC}} \mathrm{NO}_{2}$ in $\mathrm{CH}-$ box in February. Moreover, a significant reduction is also seen in January and March ( 17\% and $\sim 12 \%)$. This massive reduction of ${ }^{\mathrm{TC}} \mathrm{NO}_{2}$ in consecutive three months is seen for the first time in the last 5-years. On the other hand, IN-box also experienced a large reduction in ${ }^{\mathrm{TC}} \mathrm{NO}_{2}$ for the first time in the previous 5-years. Quantitatively $\sim 17 \%$ and $\sim 11 \%$ reduction is observed over IN-box during March and April.

Table 1. shows area averaged ${ }^{\mathrm{TC}} \mathrm{NO}_{2}$ for January-March for the last 5-years (2016-2020) over CH-box. CH-box receives 101.37 and $113.85 \mu \mathrm{mol} \mathrm{m}{ }^{-2}{ }^{\mathrm{TC}} \mathrm{NO}_{2}$ in February 

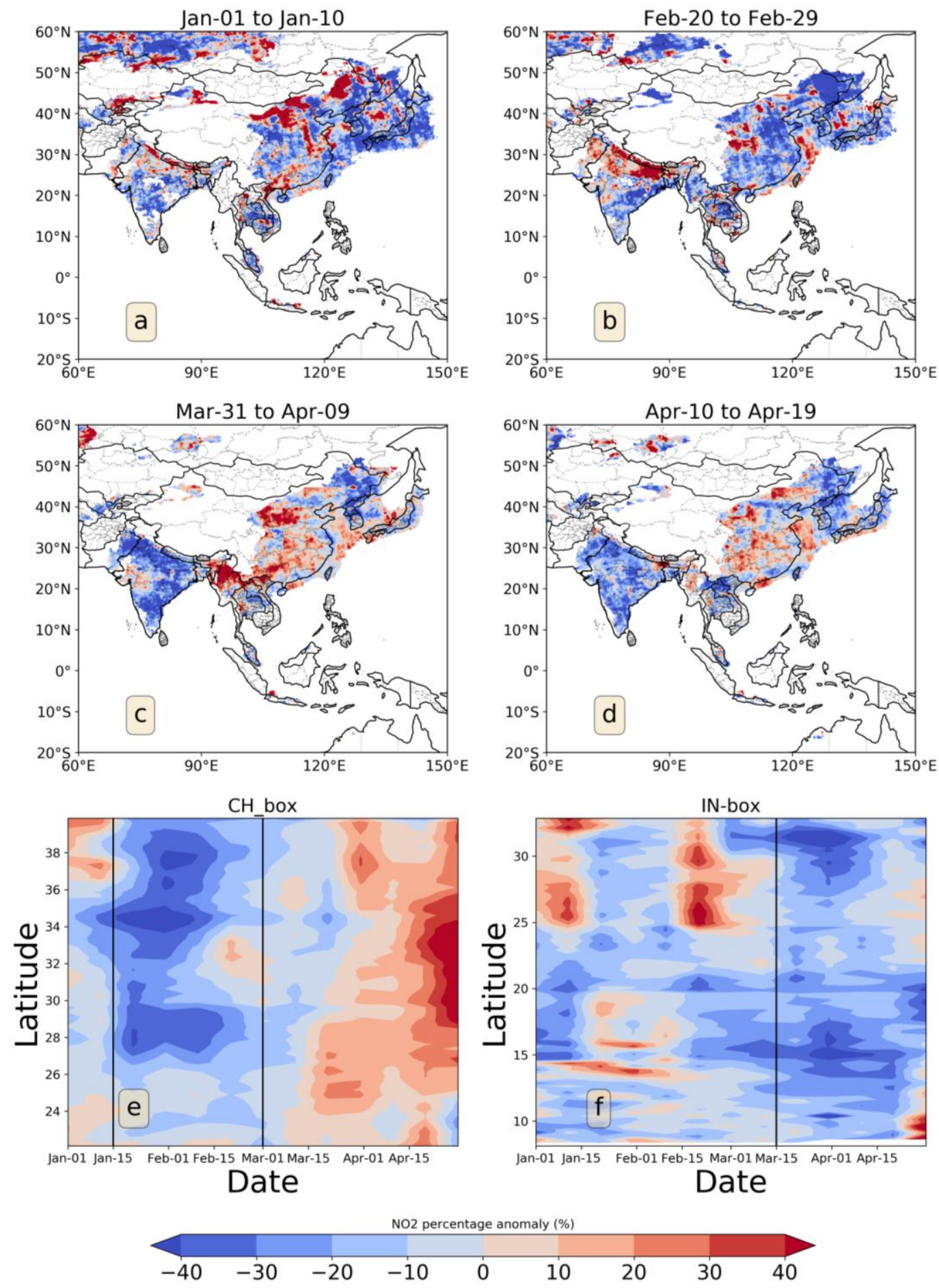

Fig. 4. 10-day anomaly of ${ }^{\mathrm{TC}} \mathrm{NO}_{2}$ in percentage for period (a) 01 to 10-January, 2020; (b) 20 to 29-February, 2020; (c) March 31 to April 9,2020 and (d) April 10 to 19, 2020. Time-Latitude plot over CH-box and IN-box is shown in (e) and (f).

and March, 2020, lowest in the last 5-years. The average ${ }^{\mathrm{TC}} \mathrm{NO}_{2}$ over IN-box was 20.97 and $21.47 \mu \mathrm{mol} \mathrm{m}{ }^{-2}$ in March and April, 2020. These average values are also the minimum seen in the last 5-years.

The transport sector is an essential source of $\mathrm{NO}_{2}$ in China and India (Garg et al., 2001; Crippa et al., 2018). Sector wise emission from EDGAR v4.3.2 shows $~ 15 \%$ emission from transport, $\sim 41 \%$ from the energy sector, $\sim 24 \%$ from manufacturing industries and construction over China in 2012 (Fig. S2(b)). Transport ( 24\%), energy sector ( 44\%), and manufacturing industries and construction $(\sim 14 \%)$ were also major $\mathrm{NO}_{\mathrm{x}}$ emitters of India in 2012 (Fig. S2(a)). Massive reduction of $\mathrm{NO}_{2}$ over $\mathrm{IN}$ and $\mathrm{CH}$-box during lockdown is most likely driven by decrease in vehicular movement. However, the energy sector is the largest emitter of $\mathrm{NO}_{2}$, and this sector shows little variation in regional scale. 


\section{Boundary Layer $\mathrm{SO}_{2}\left({ }^{\mathrm{BL}} \mathrm{SO}_{2}\right)$}

$\sim 33$ million people lived in areas with substantial $\mathrm{SO}_{2}$ pollution (Li et al., 2017). $\mathrm{SO}_{2}$ forms sulfate $\left(\mathrm{SO}_{4}{ }^{2-}\right)$ aerosols by oxidation and results in acid deposition through sulfuric acid $\left(\mathrm{H}_{2} \mathrm{SO}_{4}\right)$. Moreover, the sulfate aerosols lead to historic "London smog" and lead to more than one million premature deaths each year (Lelieveld et al., 2015). China alone is responsible for $30 \%$ emission of global $\mathrm{SO}_{2}$ (Klimont et al., 2013). Moreover, $90 \%$ of $\mathrm{SO}_{2}$ in China is produced by coal consumption (Chen and $\mathrm{Xu}, 2010)$. Coal is widely used in thermal power plants, various industries (steel, cement, and glass) and residential activities. Power plants are responsible for $30-40 \%$ of total emission and industry for another 50 $60 \%$ over China (He et al., 2012). EDGAR v4.3.2 emission database shows $\sim 33 \%$ emission from power plants, $\sim 45 \%$ from manufacturing industries and construction, $\sim 7 \%$ from residential $\sim 0.18 \%$ from transport in 2012 (Fig. S4(b)). Steady growth in emission from power plants and a decrease from the residential sector is also evident in 1970-2012 time span. A similar characteristic is also found for India. Power plants are responsible for $\sim 65 \% \mathrm{SO}_{2}$ emission, and manufacturing industries contribute $\sim 24 \%$ in India $\mathrm{SO}_{2}$ share (Fig. S5(a)).

Advances in satellite measurements provide an opportunity to study over large regions with improved accuracy. Many studies have used $\mathrm{SO}_{2}$ data from OMI due to its superior ground resolution (Fioletov et al., 2013). Long-term (20102020) monthly climatology of ${ }^{\mathrm{BL}} \mathrm{SO}_{2}$ shows high concentration over IN and CH-box in January-February-March with a strong seasonality (Fig. S5(a) and S5(b)). Several previous studies found that China had reduced $\mathrm{SO}_{2}$ emission through desulfurization of coal-fired power plants in 2005/2006 (Li et al., 2010; Xu, 2011). On the other hand, India had increased its $\mathrm{SO}_{2}$ emission (Lu et al., 2013; Li et al., 2017) due to growing electricity demand and lack of regularization. We have also found an increase of $+1.12 \mu \mathrm{mol} \mathrm{m} \mathrm{m}^{-2} \mathrm{yr}^{-1} \mathrm{BL}_{2}$ over IN-box and a decrease of $-8.76 \mu \mathrm{mol} \mathrm{m}^{-2} \mathrm{yr}^{-1} \mathrm{BL}^{\mathrm{SO}_{2}}$ over $\mathrm{CH}$-box. Hence, ${ }^{\mathrm{BL}} \mathrm{SO}_{2}$ is also detrended similar to ${ }^{\mathrm{T}} \mathrm{NO}_{2}$ using Eq. (1).

Figs. 5(a) and 5(e) show locations of coal-based large (> $2000 \mathrm{Mw}$ ) power plants over China and India. It is evident that most of the power plants are clustered around east-India $\left(80-87^{\circ} \mathrm{E}\right.$ and $\left.19-25^{\circ} \mathrm{N}\right)$ and north-central China (106$122^{\circ} \mathrm{E}$ and $30-40^{\circ} \mathrm{N}$ ). A positive anomaly is found over east-India in March (Fig. 5(b)) which becomes negative in April (Fig. 5(c)). While, the negative anomaly is found over north-central China surrounded by positive anomaly in February (Fig. 5(e)). Moreover, positive anomaly acquires completely north-central China in April (Fig. 5(f)).

${ }^{\mathrm{BL}} \mathrm{SO}_{2}$ is sensitive to strong anthropogenic sources and regional pollution. While the lifetime of $\mathrm{SO}_{2}$ is short, typically 4-48 hours (Lee et al., 2011), the ${ }^{\mathrm{BL}} \mathrm{SO}_{2}$ is used as a proxy for the location of $\mathrm{SO}_{2}$ emissions. Long-time climatology (Fig. S5(a)) shows high ${ }^{\mathrm{BL}} \mathrm{SO}_{2}$ around power plants and coal dependent (or consuming) industries, which is also found in previous studies (Li et al., 2017; van der A et al., 2017). Power System Operation Corporation (POSOCO, India, "https://posoco.in/") shows a reduction in evening peak power demand from March 22, onwards (Fig. S(6)). The decrease is very distinct and was not found in previous 4-years (2017-2020). This unusual phenomenon may be caused by
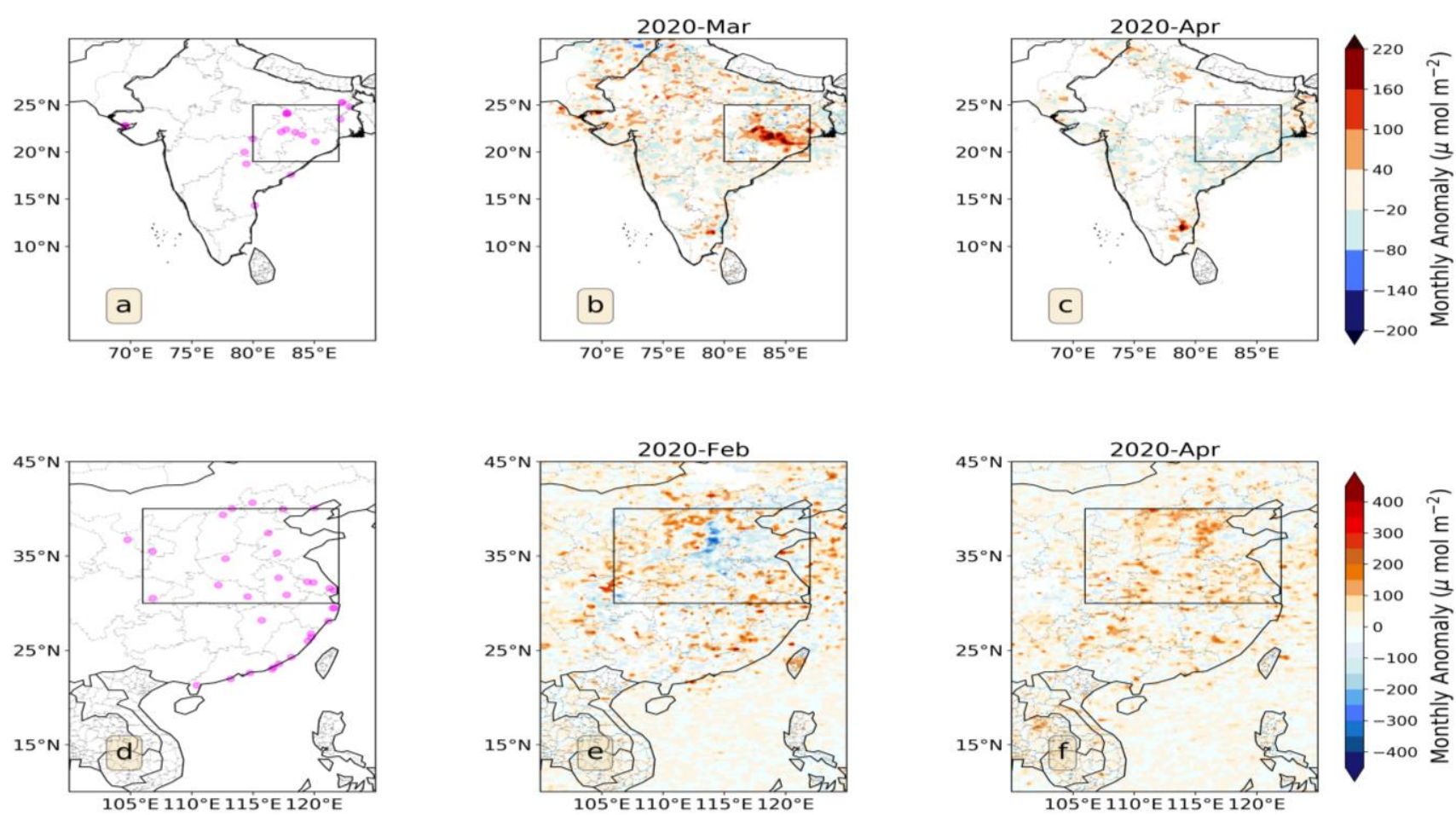

Fig. 5. Position of large (> $2000 \mathrm{Mw}$ ) coal based power plants over India and China is shown in (a) and (d). Monthly anomaly

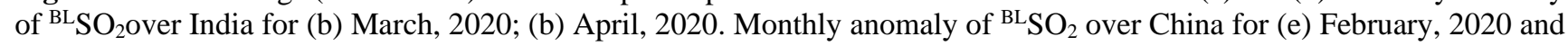
(f) April, 2020 . 
large-scale lockdown in India from March 25, 2020. As a result, we found a large decrease in ${ }^{{ }^{\mathrm{BL}}} \mathrm{SO}_{2}$ over east-India. Quantitatively $17 \%$ (Fig. 3(d)) reduction of ${ }^{\mathrm{BL}} \mathrm{SO}_{2}$ from long term mean is observed over east-India during April. Averaged density of $\mathrm{SO}_{2}$ is $96.82 \mu \mathrm{mol} \mathrm{m}{ }^{-2}$ (Table 1), lowest in the last five-years. While, area averaged ${ }^{{ }^{B L}} \mathrm{SO}_{2}$ does not show significant reduction in February, 2020, despite fragmented negative anomaly found over north-central China. Hence, the recent scenario of ${ }^{\mathrm{BLSO}_{2}}$ leads to conclude that recent lockdown reduced the $\mathrm{SO}_{2}$ level on a regional scale, where cluster of thermal power stations observed, due to less demand for electricity.

\section{SUMMARY}

CO over north-central China showed a significant reduction during the lockdown period. Whereas $\mathrm{CO}_{700}$ over south-east China did not get affected by lockdown, as the biomass burning in Indo-China peninsula remained high. A $6.5 \%(5.1 \%)$ reduction in $\mathrm{CO}_{700}$ is observed over north-central China in February (March), 2020. Satellite data shows, $\mathrm{NO}_{2}$ decreases significantly during the current lockdown period over China (in February-March, 2020) and India (in MarchApril, 2020) loosely denoted as $\mathrm{CH}$-box and IN-box in the text. China experienced a maximum reduction in $\mathrm{NO}_{2}$ in February 2020. India (China) shows a maximum reduction, $17 \%$ (25\%) from the last 10-years (2010-2020) mean, in March (February), 2020. The reduction is maximum in the last 5-years (2016-2020). $\mathrm{NO}_{2}$ shows large-scale reduction (country level) while $\mathrm{SO}_{2}$ shows reduction in much lower scale (state level). $\mathrm{NO}_{2}$ and $\mathrm{SO}_{2}$ have almost similar anthropogenic sources, i.e., burning of coal or oil. Power plants are a major contributor for both the pollutants. The main difference is traffic, which is more important for $\mathrm{NO}_{2}$. $\mathrm{NO}_{\mathrm{x}}$ emission factor (emission/fossil fuel unit) is higher from the transport sector than energy and industry (Crippa et al., 2018). Hence, a large reduction of $\mathrm{NO}_{2}$ over India and China shows that vehicular transport was maximum affected during the lockdown period. While the less demand of energy during lockdown leads to less emission of $\mathrm{SO}_{2}$ from regions where coal fired power plants are dominant. A 17\% reduction of ${ }^{\mathrm{BL}^{2}} \mathrm{SO}_{2}$ is observed in east India, a region having several power plants. Moreover, few regions also show higher than normal $\mathrm{SO}_{2}$ emission during the lockdown period.

The large-scale lockdown invoked in two major Asian economies caused a significant reduction in air pollution. Our analysis demonstrated that wide spread restriction of vehicular movement was responsible for a significant reduction of large-scale $\mathrm{NO}_{2}$ emission. While, lesser demand of energy led to a reduced level of atmospheric $\mathrm{SO}_{2}$ over a smaller spatial scale.

\section{ACKNOWLEDGMENTS}

The Indian Institute of Tropical Meteorology, Pune (IITM), is fully supported by the Earth System Science Organization of Ministry of Earth Science, Govt. of India. We thank the Director, IITM and R. Krishnan, Executive Director, Center for Climate Change Research, IITM for their encouragement.

\section{SUPPLEMENTARY MATERIAL}

Supplementary data associated with this article can be found in the online version at https://aaqr.org/

\section{REFERENCES}

Andersen, K.G., Rambaut, A., Lipkin, W.I., Holmes, E.C. and Garry, R.F. (2020). The proximal origin of SARSCoV-2. Nat. Med. 26: 450-452. https://doi.org/10.1038/s 41591-020-0820-9

Barbuzano, J. (2020). Coronavirus lockdown brings clean air to Spanish cities. Eos 101. https://doi.org/10.1029/202 0EO142570

Beirle, S., Boersma, K.F., Platt, U., Lawrence, M.G. and Wagner, T. (2011). Megacity emissions and lifetimes of nitrogen oxides probed from space. Science 333: 17371739. https://doi.org/10.1126/science.1207824

Boersma, K.F., Jacob, D.J., Trainic, M., Rudich, Y., DeSmedt, I., Dirksen, R. and Eskes, H.J. (2009). Validation of urban $\mathrm{NO}_{2}$ concentrations and their diurnal and seasonal variations observed from the SCIAMACHY and OMI sensors using in situ surface measurements in Israeli cities. Atmos. Chem. Phys. 9: 3867-3879. https://doi.org/10.5194/acp-9-3867-2009

Bogoch, I.I., Watts, A., Thomas-Bachli, A., Huber, C., Kraemer, M.U.G. and Khan, K. (2020). Pneumonia of unknown aetiology in Wuhan, China: Potential for international spread via commercial air travel. J. Travel Med. 27: taaa008. https://doi.org/10.1093/jtm/taaa008

Chen, W. and Xu, R. (2010). Clean coal technology development in China. Energy Policy 38: 2123-2130. https://doi.org/10.1016/j.enpol.2009.06.003

Cooper, R.N., Houghton, J.T., McCarthy, J.J. and Metz, B. (2002). Climate change 2001: The scientific basis by J. T. Houghton; Climate change 2001: Impacts, adaptation, and vulnerability by James J. McCarthy; Climate Change 2001: Mitigation by Bert Metz. Foreign Aff. 81: 208. https://doi.org/10.2307/20033020

Crippa, M., Guizzardi, D., Muntean, M., Schaaf, E., Dentener, F., van Aardenne, J.A., Monni, S., Doering, U., Olivier, J.G.J., Pagliari, V. and Janssens-Maenhout, G. (2018). Gridded emissions of air pollutants for the period 1970-2012 within EDGAR v4.3.2. Earth Syst. Sci. Data 10: 1987-2013. https://doi.org/10.5194/essd-10-1987-2018

Fioletov, V.E., McLinden, C.A., Krotkov, N., Yang, K., Loyola, D.G., Valks, P., Theys, N., van Roozendael, M., Nowlan, C.R., Chance, K., Liu, X., Lee, C. and Martin, R.V. (2013). Application of OMI, SCIAMACHY, and GOME-2 satellite $\mathrm{SO}_{2}$ retrievals for detection of large emission sources. J. Geophys. Res. 118: 11399-11418. https://doi.org/10.1002/jgrd.50826

Frantzeskakis, J.M. and Frantzeskakis, M.J. (2006). Athens 2004 Olympic Games: Transportation planning, simulation and traffic management. ITE J. 76: 26-32. https://trid.trb.org/view/795755

Friedman, M.S., Powell, K.E., Hutwagner, L., Graham, 
L.M. and Teague, W.G. (2001). Impact of changes in transportation and commuting behaviors during the 1996 Summer Olympic Games in Atlanta on air quality and childhood asthma. JAMA 285: 897-905. https://doi.org/1 0.1001/jama.285.7.897

Garg, A., Shukla, P.R., Bhattacharya, S. and Dadhwal, V.K. (2001). Sub-region (district) and sector level $\mathrm{SO}_{2}$ and $\mathrm{NO}_{\mathrm{x}}$ emissions for India: Assessment of inventories and mitigation flexibility. Atmos. Environ. 35: 703-713. https://doi.org/10.1016/S1352-2310(00)00316-2

Ghude, S.D., Fadnavis, S., Beig, G., Polade, S.D. and van der A, R.J. (2008). Detection of surface emission hot spots, trends, and seasonal cycle from satellite-retrieved $\mathrm{NO}_{2}$ over India. J. Geophys. Res. 113: D20305. https://doi.org/10.1029/2007JD009615

He, H., Li, C., Loughner, C.P., Li, Z., Krotkov, N.A., Yang, K., Wang, L., Zheng, Y., Bao, X., Zhao, G. and Dickerson, R.R. (2012). $\mathrm{SO}_{2}$ over central China: Measurements, numerical simulations and the tropospheric sulfur budget. J. Geophys. Res. 117. https://doi.org/10.1029/2011JD01 6473

Kang, H., Zhu, B., van der A, R.J., Zhu, C., de Leeuw, G., Hou, X. and Gao, J. (2019). Natural and anthropogenic contributions to long-term variations of $\mathrm{SO}_{2}, \mathrm{NO}_{2}, \mathrm{CO}$, and AOD over East China. Atmos. Res. 215: 284-293. https://doi.org/10.1016/j.atmosres.2018.09.012

Kaufman, Y.J., Justice, C.O., Flynn, L.P., Kendall, J.D., Prins, E.M., Giglio, L., Ward, D.E., Menzel, W.P. and Setzer, A.W. (1998). Potential global fire monitoring from EOS-MODIS. J. Geophys. Res. 103: 32215-32238. https://doi.org/10.1029/98JD01644

Klimont, Z., Smith, S.J. and Cofala, J. (2013). The last decade of global anthropogenic sulfur dioxide: 2000-2011 emissions. Environ. Res. Lett. 8: 014003. https://doi.org/ 10.1088/1748-9326/8/1/014003

Krotkov, N.A, Li, C. and Leonard, P. (2015). OMI/Aura Sulfur Dioxide $\left(\mathrm{SO}_{2}\right)$ Total Column L3 1 day Best Pixel in 0.25 degree x 0.25 degree V3. Greenbelt, MD, USA, Goddard Earth Sciences Data and Information Services Center (GES DISC). https://doi.org/10.5067/Aura/OMI/ DATA3008

Krotkov, N.A., Lamsal, L.N., Celarier, E.A., Swartz, W.H., Marchenko, S.V., Bucsela, E.J., Chan, K.L., Wenig, M. and Zara, M. (2017). The version $3 \mathrm{OMI} \mathrm{NO}_{2}$ standard product. Atmos. Meas. Tech. 10: 3133-3149. https://doi.o rg/10.5194/amt-10-3133-2017

Lee, C., Martin, R.V., van Donkelaar, A., Lee, H., Dickerson, R.R., Hains, J.C., Krotkov, N., Richter, A., Vinnikov, K. and Schwab, J.J. (2011). $\mathrm{SO}_{2}$ emissions and lifetimes: Estimates from inverse modeling using in situ and global, space-based (SCIAMACHY and OMI) observations. J. Geophys. Res. 116: D06304. https://doi. org/10.1029/2010JD014758

Lee, J.T., Son, J.Y. and Cho, Y.S. (2007). Benefits of mitigated ambient air quality due to transportation control on childhood asthma hospitalization during the 2002 summer Asian games in Busan, Korea. J. Air Waste Manage. Assoc. 57: 968-973. https://doi.org/10.3155/104 7-3289.57.8.968
Lelieveld, J., Evans, J.S., Fnais, M., Giannadaki, D. and Pozzer, A. (2015). The contribution of outdoor air pollution sources to premature mortality on a global scale. Nature 525: 367-371. https://doi.org/10.1038/nature15371

Li, C., Zhang, Q., Krotkov, N.A., Streets, D.G., He, K., Tsay, S.C. and Gleason, J.F. (2010). Recent large reduction in sulfur dioxide emissions from Chinese power plants observed by the Ozone Monitoring Instrument. Geophys. Res. Lett. 37: L08807. https://doi.org/10.1029/ 2010GL042594

Li, C., McLinden, C., Fioletov, V., Krotkov, N., Carn, S., Joiner, J., Streets, D., He, H., Ren, X., Li, Z. and Dickerson, R.R. (2017). India is overtaking China as the world's largest emitter of anthropogenic sulfur dioxide. Sci. Rep. 7: 14304. https://doi.org/10.1038/s41598-01714639-8

Liu, F., Zhang, Q., van der A, R.J., Zheng, B., Tong, D., Yan, L., Zheng, Y. and He, K. (2016). Recent reduction in $\mathrm{NO}_{x}$ emissions over China: Synthesis of satellite observations and emission inventories. Environ. Res. Lett. 11: 114002. https://doi.org/10.1088/1748-9326/11/ $11 / 114002$

Lu, Z., Streets, D.G., de Foy, B. and Krotkov, N.A. (2013). Ozone monitoring instrument observations of interannual increases in $\mathrm{SO}_{2}$ emissions from Indian coal-fired power plants during 2005-2012. Environ. Sci. Technol. 47: 13993-14000. https://doi.org/10.1021/es4039648

Maas, R., grennfelt, P., Amann, M., Harnett, B., Kerr, J., Berton, E., Pritula, D., Reiss, I., Almodovar, P., Héroux, M.E., Fowler, D., Wright, D., de Wit, H.A., Tørseth, K., Mareckova, K., LeGall, A.C., Rabago, I., Hettelingh, J.P., Haeuber, R., ... Reis, S. (2016). Towards cleaner air: Scientific assessment report 2016 - Summary for policymakers. United Nations Economic Commission for Europe (UNECE). https://icpvegetation.ceh.ac.uk/sites/d efault/files/Towards\%20Cleaner\%20Air\%20-\%20Summ ary $\% 20$ for $\% 20$ Policymakers $\% 202016 \% 20 \% 28$ English $\%$ 20Version\%29.pdf

Monks, P.S., Granier, C., Fuzzi, S., Stohl, A., Williams, M.L., Akimoto, H., Amann, M., Baklanov, A., Baltensperger, U., Bey, I., Blake, N., Blake, R.S., Carslaw, K., Cooper, O.R., Dentener, F., Fowler, D., Fragkou, E., Frost, G.J., Generoso, S., ... von Glasow, R. (2009). Atmospheric composition change: Global and regional air quality. Atmos. Environ. 43: 5268-5350. https://doi.org/10.1016/ j.atmosenv.2009.08.021

Myhre, G., Shindell, D. and Pongratz, J. (2014). Anthropogenic and Natural Radiative Forcing, In Climate Change 2013: The Physical Science Basis; Working Group I Contribution to the Fifth Assessment Report of the Intergovernmental Panel on Climate Change, Stocker, T. (Ed.), Ludwig-Maximilians-Universität München, Cambridge, pp. 659-740.

Ramachandran, A., Jain, N.K., Sharma, S.A. and Pallipad, J. (2013). Recent trends in tropospheric $\mathrm{NO}_{2}$ over India observed by SCIAMACHY: Identification of hot spots. Atmos. Pollut. Res. 4: 354-361. https://doi.org/10.5094/A PR.2013.040

Raub, J.A. and Benignus, V.A. (2002). Carbon monoxide and 
the nervous system. Neurosci. Biobehav. Rev. 26: 925940. https://doi.org/10.1016/S0149-7634(03)00002-2

Sabljic, A. (2009). Environmental and ecological chemistry - Volume II, EOLSS Publications.

Saraswat, R. and Saraswat, D.A. (2020). Research opportunities in pandemic lockdown. Science 368: eabc3372. https://doi.org/10.1126/science.abc3372

Sawlani, R., Agnihotri, R., Sharma, C., Patra, P.K., Dimri, A.P., Ram, K. and Verma, R.L. (2019). The severe Delhi SMOG of 2016: A case of delayed crop residue burning, coincident firecracker emissions, and atypical meteorology. Atmos. Pollut. Res. 10: 868-879. https://doi.org/10.1016/ j.apr.2018.12.015

Shen, J., Tang, A., Liu, X., Kopsch, J., Fangmeier, A., Goulding, K. and Zhang, F. (2011). Impacts of pollution controls on air quality in Beijing during the 2008 Olympic Games. J. Environ. Qual. 40: 37-45. https://doi.org/10.21 34/jeq2010.0360

Susskind, J., Blaisdell, J.M. and Iredell, L. (2014). Improved methodology for surface and atmospheric soundings, error estimates, and quality control procedures: The AIRS science team version-6 retrieval algorithm. J. Appl. Remote Sens. 8: 084994. https://doi.org/10.1117/1.JRS.8. 084994

van der A, R.J., Mijling, B., Ding, J., Koukouli, M.E., Liu, F., Li, Q., Mao, H. and Theys, N. (2017). Cleaning up the air: effectiveness of air quality policy for $\mathrm{SO}_{2}$ and $\mathrm{NO}_{x}$ emissions in China. Atmos. Chem. Phys. 17: 1775-1789. https://doi.org/10.5194/acp-17-1775-2017

Wang, K.C., Dickinson, R.E., Su, L. and Trenberth, K.E. (2012). Contrasting trends of mass and optical properties of aerosols over the Northern Hemisphere from 1992 to 2011. Atmos. Chem. Phys. 12: 9387-9398. https://doi.org/ 10.5194/acp-12-9387-2012

Wang, Q. and Su, M. (2020). A preliminary assessment of the impact of COVID-19 on environment - A case study of China. Sci. Total Environ. 728: 138915. https://doi.org/ 10.1016/j.scitotenv.2020.138915

Wang, T., Nie, W., Gao, J., Xue, L.K., Gao, X.M., Wang, X.F., Qiu, J., Poon, C.N., Meinardi, S., Blake, D., Wang, S.L., Ding, A.J., Chai, F.H., Zhang, Q.Z. and Wang, W.X.
(2010). Air quality during the 2008 Beijing Olympics: secondary pollutants and regional impact. Atmos. Chem. Phys. 10: 7603-7615. https://doi.org/10.5194/acp-107603-2010

Witte, J.C., Schoeberl, M.R., Douglass, A.R., Gleason, J.F., Krotkov, N.A., Gille, J.C., Pickering, K.E. and Livesey, N. (2009). Satellite observations of changes in air quality during the 2008 Beijing Olympics and Paralympics. Geophys. Res. Lett. 36: L17803. https://doi.org/10.1029/2 009GL039236

World Health Organization (WHO) (2016). Ambient air pollution: A global assessment of exposure and burden of disease, World Health Organization.

World Health Organization (WHO) (2020). Coronavirus disease 2019 (COVID-19): Situation report, 100. World Health Organization. https://apps.who.int/iris/handle/106 $65 / 332053$

$\mathrm{Xu}, \mathrm{Y}$. (2011). Improvements in the operation of $\mathrm{SO}_{2}$ scrubbers in China's coal power plants. Environ. Sci. Technol. 45: 380-385. https://doi.org/10.1021/es1025678

Yin, S., Wang, X., Zhang, X., Guo, M., Miura, M. and Xiao, Y. (2019). Influence of biomass burning on local air pollution in mainland Southeast Asia from 2001 to 2016. Environ. Pollut. 254: 112949. https://doi.org/10.1016/j.e nvpol.2019.07.117

Zhang, X., Liu, J., Han, H., Zhang, Y., Jiang, Z., Wang, H., Meng, L., Li, Y.C. and Liu, Y. (2020). satellite-observed variations and trends in carbon monoxide over Asia and their sensitivities to biomass burning. Remote Sens. 12: 830. https://doi.org/10.3390/rs12050830

Zhao, Y., Nielsen, C.P., McElroy, M.B., Zhang, L. and Zhang, J. (2012). CO emissions in China: Uncertainties and implications of improved energy efficiency and emission control. Atmos. Environ. 49: 103-113. https://doi.org/10.1016/j.atmosenv.2011.12.015

Received for review, May 17, 2020

Revised, July 12, 2020

Accepted, July 12, 2020 